\title{
Shallot Basal Bulb Rot Management through Integration of Trichoderma asperellum, Composted Plant Residues and Natural Mulch
}

\author{
Nurmasita Ismail ${ }^{1}$, Ade Rosmana $^{1 *}$ (D), Sylvia Sjam ${ }^{1}$ and Ratnawati Ratnawati² \\ ${ }^{1}$ Plant Pests and Diseases Department, Faculty of Agricurture, Hasanuddin University, Makassar 90245, \\ Indonesia. ${ }^{2}$ Agrotechnology Department, Faculty of Agriculture, Alkhairaat University, Palu 94221, Indonesia.
}

\begin{abstract}
Basal bulb rot (BBR) of shallot caused by Fusarium oxysporum $\mathrm{f}$. sp. cepae is one of the highly deleterious diseases on shallot, Allium cepa L. var ascalonicum Backer. in Indonesia. This study aimed to assess the potency of organic mulch, composted plant residues, and endophytic Trichoderma asperellum to control this disease. Treatment with mulch alone, mulch plus compost, mulch plus $T$. asperellum, and combination of all the three provided the decrease of BBR incidence by $15 \%, 20 \%, 29 \%$, and $39 \%$ and the increase of shallot productivity by $22 \%, 66 \%, 84 \%$, and $125 \%$, respectively. Observation of another treatment impact on the fungal occurrence at harvest time indicated that their population in soil increased by $671 \%, 771 \%, 257 \%$, and $814 \%$ and the fungal colonization in root tissues mounted by $31 \%$, $\mathbf{7 7 \%}, \mathbf{7 7 \%}$, and $\mathbf{7 4 \%}$, respectively. The introduced Trichoderma was found predominantly, especially in leaf tissues of inoculated shallot. These data showed that all the treatments were able to control BBR disease. However, the most effective was the mulch in combination with compost and $T$. asperellum. Therefore, large-scale disease control could take advantage of this integration.
\end{abstract}

Keywords: Bulb rot, Compost, Endophytic Trichoderma, Fungal population, Fungal colonization, Mulch

*Correspondence: aderosmana65@gmail.com

(Received: June 14, 2020; accepted: August 12, 2020)

Citation: Ismail N, Rosmana A, Sjam S, Ratnawati R. Shallot Basal Bulb Rot Management through Integration of Trichoderma asperellum, Composted Plant Residues and Natural Mulch. J Pure Appl Microbiol. 2020;14(3):1779-1788. doi: 10.22207/ JPAM.14.3.16

(C) The Author(s) 2020. Open Access. This article is distributed under the terms of the Creative Commons Attribution 4.0 International License which permits unrestricted use, sharing, distribution, and reproduction in any medium, provided you give appropriate credit to the original author(s) and the source, provide a link to the Creative Commons license, and indicate if changes were made. 


\section{INTRODUCTION}

Shallot (Allium cepa L. var ascalonicum

Backer) is the second major horticultural crop after hot peppers in Indonesia. With the area of 110,000 ha, this country is by far the largest producer of shallot in the world (Fadhilah et al., 2014; Wandschneide et al., 2013). Nevertheless, Indonesia is not self-sufficient in shallot production resulting in an annual import of 90,000 tones (Wandsheneide et al., 2013). Shallot diseases, especially basal bulb rot (BBR) is one of the limiting factors towards a complete reduction of imports. It can cause losses of up to $43 \%$ of production, depending on the environmental conditions (Fadhilah et al., 2014). Infection of the pathogen, Fusarium oxysporum f. sp. cepae, on roots and a basal bulb plate at any stage development, cause rot of bulb (Entwistle, 1990). In the field, the first symptom emerges as warping, yellowing and dieback of leaves, starting at the ends and evolving downward. Rot and Red-brown discoloration expand at the margin of the root-basal plate, and bulbs and stems get reddish-purple discoloration as the Fusarium ties up from the plate into scales. With the progression of the disease, the whole plant can crumple, and when the fungus infects the shallot at maturity, the infestation can cause serious postharvest losses (Entwistle, 1990; Ozer et al.,2003).

In Palu Valley, the major shallot-producing region of Central Sulawesi Indonesia, the chemical is the predominant method for controlling pests and diseases including BBR. Several studies indicated that application of pesticides on shallot crops caused pest and pathogen resistance, soil quality degradation, and decrease of natural enemies (Adiyoga and de Putter, 2015; Arfan et al., 2018). The availability of a sustainable method supporting environmental and human health for controlling the soil-borne diseases is highly desirable. In the integrated pest management principal, biological control and cultural practices are methods supporting the disease reduction to the level of economically viable, with an accompanying decrease in the use of the chemicals (Bajwa and Kogan, 2004; Pane et al., 2013).

Research on the Trichoderma use to shallot disease control indicates promise for this approach (Ratnawati et al., 2020). Trichoderma species are free-living non-pathogenic fungi colonizing plant roots as opportunistic, avirulent plant symbionts. This colonization closes with many aspects typical of endophytic associations and, thereby, can protect from plant disease (Harman et al., 2004). Beside roots, Trichoderma also present as an endophyte that can be found in stem and leaf tissues of both annual and perennial crops (Bailey et al., 2009; Rosmana et al., 2018b; Ratnawati et al., 2020). Their action in pathogen inhibition was antibiosis, mycoparasitic, and inducing systemic plant resistance (Harman, 2011). Among the cultural practices that could be compatible with the use of Trichoderma are compost fertilization and mulch application. Compost is an organic matter obtained from biological decomposition of different waste types that are rich in nutrient and microorganisms (Pane et al., 2011; Segarra et al., 2013).Treatment of compost through soil amendment has been proved can control plant disease caused by soilborne pathogens including Thielaviopsis basicola, Verticillium dahlia Pythium ultimum, Rhizoctonia solani and Sclerotinia minor (Bonanomi et al., 2010; Pane et al., 2011; Naseri, 2013). Additionally, Retention of compost in the soil may reduce runoff and erosion, improves soil physical characteristics and nutrient-supplying capacity, increases soil organic matter content and microbial biomass, and reduce nutrient losses (Bhupinderpal-Singh and Rengel, 2007). Further, the incorporation of compost with useful microbes has shown to offer more disease suppression than just by using single compost or beneficial microorganism (Ros et al.,2017; Rosmana et al., 2018a). Then mulches are used to cover the soil surface and made from organic or synthetic materials (Chalker-Scott, 2007). Application of these mulches offers plant protection against soil-borne pathogens, besides, to conserve soil moisture and to improve soil temperature (Kareem et al., 2012). Study on capsicum indicates that compost amendment, in combination with organic mulches, reduces high losses by Pythium aphanidermatum and Meloidogyne incognita (Stirling and Eden, 2008). Management of plant diseases by using beneficial microorganisms and plant residues in the shallot crop area used in this research is not well known. Therefore, the evaluation of their usage is planned.

The research aimed to assess the application of composted plant residues, plant 
residue mulch, Trichoderma asperellum, and its combination in two and three to control BBR disease and improve the production of shallot. In addition to these two objects, fungal diversity and population in the soil and fungal endophyte colonization in shallot tissues were also evaluated.

\section{MATERIALS AND METHODS \\ Preparation of $T$. asperellum inoculum, compost and mulch}

T. asperellum was isolated previously from shallot crop in Palu Valley, where the research realized and called as $T$. asperellum strainT3RZR (Ratnawatiet al.,2020). For inoculum preparation, a sterilized plastic bag containing around $100 \mathrm{~g}$ of rice grain medium was inoculated by the fungus of 7-day culture in PDA medium origin. Then, after seven days incubation at a temperature of $26^{\circ} \mathrm{C}-28^{\circ} \mathrm{C}$ and humidity of $80 \%-90 \%$, Trichoderma was harvested, dried, and milled to form a smooth powder (Rosmana et al., 2016).

Raw materials of compost consisting of Imperata weed, gliricidia leaf, and siam grass were collected from around the field. These plant residues in the ratio of fresh weigh 1: 1: 1 were chopped using a shredder machine, mixed, and put in a plastic bag. The bag was aired by making holes in its surface by around $10 \mathrm{~cm}$ of distance and then incubated for one month. Before applying in the field, compost passed one month of curing period. Mulch was prepared from Imperata weed after passing one month of air-drying.

\section{Field trial}

Arrangement of randomized block design was used in the field trial. This experiment included four treatments as follows: mulch, the combination of mulch and compost, the combination of mulch and $T$. asperellum, and the combination of mulch, T. asperellum and compost. Each treatment consisted of a plot of $1.2 \mathrm{~m} \times 10$ $\mathrm{m}$ with 400 shallot plants and was repeated four times. For comparison, the control was made without any application of mulch, compost and Trichoderma.

Treatment of $T$. asperelum, composted plant residues, and mulch was carried out before planting. The fungus was applied through soil drenching with a dose of $4 \mathrm{~g} \mathrm{~L}^{-1}$ of water $\mathrm{m}^{-2}$ of the plot. However, $4 \mathrm{~g}$ of this fungus was mixed first with $1 \mathrm{~kg}$ of compost when in combination.
The compost in the dose of $1 \mathrm{~kg} \mathrm{~m}-2$ of the plot was applied through soil amendment. Mulch was treated through the covering of the plot surface.

BBR disease developed as natural infection from the soil in the field. Then, the impact of treatments was evaluated through disease incidence on shallot clump, the fungal population in the soil, fungal colonization in root and leaf tissues, and shallot productivity. Constant and continuous observation of BBR incidence sampled from twenty-five shallots per plot. Measurement of this incidence used the formulation of $I C=n / N$ where IC is the incidence, $n$ is the leaves number showing symptoms of curving, yellowing or dieback, and $\mathrm{N}$ is the total leaves number observed per clump. Shallot bulb productivity was sampled from one meter square per plot and weighed in the form of fresh after removing the attached soil. For calculation purposes, the data of this productivity employed kilogram per hectare.

For evaluation of soil fungi populations per plot, five samples containing $100 \mathrm{~g}$ of soil, respectively, were dug from around shallot clump at harvest time, 63 days post-planting. Dilution method was used with a sampling of one gram of soil for each treatment. After four-time dilution, $1 \mathrm{~mL}$ from the last dilution was inoculated into PDA medium and evenly distributed to all medium surfaces, by using a sterile spatula. Then, the growing fungi were distinguished, calculated, and identified. Further, five shallots per plot were sampled at the same time for observation of endophytic fungi. Their root and leaf were chopped into $0.5 \mathrm{~cm}$ portions. Five of these portions were separately surface-sterilized using the method of Arnold et al. (2003). These all were then inoculated into PDA medium in Petri dish.

While incubation of these Petri dishes, the occurrence of fungi, including Trichoderma was examined, and their colonization was calculated according to the formula used previously (Ratnawati et al., 2020). The fungi found in soil and parts of root and leaf were identified by using taxonomic keys of Barnett and Hunter (1998) and Kiffer and Morelet (1997).

\section{Statistical analysis}

BBR disease incidence, production of shallot, the fungal population in soil, and fungal colonization in root and leaf tissues were analyzed with or without data transformation after testing 
for normality using skewness and kurtosis. If the data is not distributed normally, data is transformed to $\sqrt{ } \mathrm{x}$. For assessing the significance between the mean of treatment, the Duncan's Multiple Range Test (DMRT) was then used.

\section{RESULTS}

\section{Basal bulb rot disease incidence}

Basal bulb rot (BBR) disease appeared on shallot in the field at 21 days after planting, and since this time, all treatments have shown their efficacy against the disease. The BBR incidence both in treated and untreated increased with increasing age of the shallot. At 63 days postplanting, the incidence in untreated shallot was $70 \%$. Whereas, the incidence in shallot treated with mulch alone, the combination of mulch and compost, the combination of mulch and T. asperellum, and the integration of the three was 59\%, 56\%, 50\%, 43\%. Therefore, the efficacy of treatment was $16 \%, 20 \%, 29 \%$, and $39 \%$, respectively (Fig.1). Statistical analysis indicated

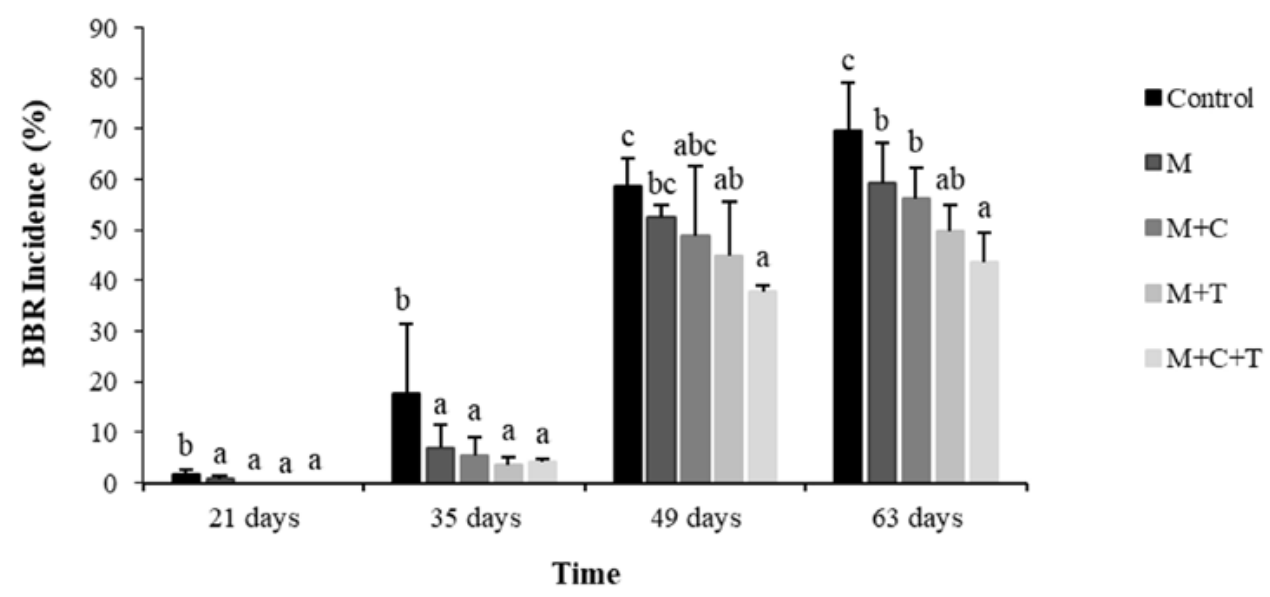

Fig. 1. Basal bulb rot incidence on shallot 21 until 63 days after treatment by mulch, mulch plus compost, mulch plus Trichoderma asperellum, and mulch plus compost plus $T$. asperellum $\mathrm{M}=$ mulch, $\mathrm{C}=$ compost, $\mathrm{T}=\mathrm{T}$. asperellum. Means of incidence at the same time, followed by the same letter are not significantly different according to DMRT $(p \leq 0.05)$. Vertical bars show standard errors of means.

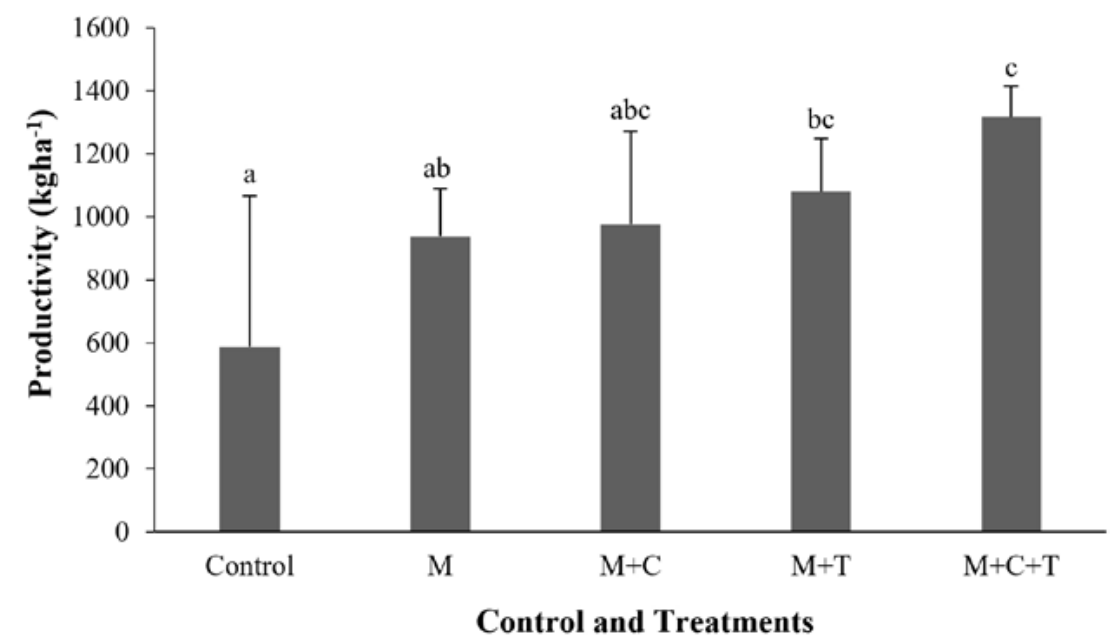

Fig. 2. Shallot productivity harvested at 63 days after treatment by mulch, mulch plus compost, mulch plus Trichoderma asperellum, and mulch plus compost and $T$. asperellum. $\mathrm{M}=$ mulch, $\mathrm{C}=$ compost, $\mathrm{T}=\mathrm{T}$. asperellum. Means of incidence at the same time, followed by the same letter are not significantly different according to DMRT $(p \leq 0.05)$. Vertical bars show standard errors of means. 
that by comparing to the control, these treatments were significantly different $(P \leq 0.05)$. The fourth treatment was significantly different from others, except with the third treatment.

The decrease of BBR incidence related apparently with the increase of shallot productivity. In untreated shallot, the productivity was 586.4 $\mathrm{kg} \mathrm{ha}^{-1}$. At the same time in the treated one consisting mulch, mulch plus compost, mulch plus Trichoderma and combination of mulch, compost, and Trichoderma reached $937.0 \mathrm{~kg} \mathrm{ha}^{-1}, 975.6 \mathrm{~kg}$ $\mathrm{ha}^{-1}, 1079.9 \mathrm{~kg} \mathrm{ha}^{-1}$, and $1316.9 \mathrm{~kg} \mathrm{ha}^{-1}$, thus an increase in productivity of $60,66,84$, and $125 \%$, respectively (Fig. 2). However, the productivity in the control was only significant $(P \leq 0.05)$ with the third and fourth treatment.

Fungal population in soil and colonization in plant tissues

Observation of soil fungi at harvesting time, 63 days post-planting indicated that in untreated shallot was just found Aspergillus morphospecies $1, A$. niger, and Penicillium with the total population of $8.8 \times 10^{4} \mathrm{cfu} \mathrm{g}^{-1}$ soil. While in those treated by mulch was found Aspergillus morphospecies $1, A$. fumigatus, Penicillium, and Paecylomyces with the total population of $67.5 \mathrm{x}$ $10^{4} \mathrm{cfug}^{-1}$ soil. Then in those treated with mulch plus compost was found Aspergillus morphospecies 1 , A. fumigatus, Penicillium, Fusarium oxysporum, and Paecillomices with the total of $77.5 \times 10^{-4}$ cfug $^{-1}$ soil. Next in those treated with mulch plus T. asperellum was found Trichoderma, Aspergillus morphospecies 1 , A. fumigatus, and Penicillium with the total population of $31,3 \times 10^{4} \mathrm{cfug}^{-1}$ soil. Last, in those treated by combination of three, was discovered Aspergillus morphospecies1, A. fumigatus, A. niger, A. flavus, Penicillium, and $F$. oxysporum with the total of $80 \times 10^{4} \mathrm{cfug}^{-1}$ soil (Fig. 3 ). The treatments tended, therefore, to increase the number and the population of fungal species. Statistically, between applications and control and between each treatment was not significantly different.

Isolation of endophytic fungi from plant tissues at harvest time, 63 days after planting showed that one until three species in leaf tissues and five until six species in root tissues were identified. In leaf tissues, included T. asperellum, Aspergillus morphospesies 1, and Fusarium oxysporum. While in root tissues consisted of T. asperellum, F. oxysporum, Fusarium morphospecies 1, Fusarium morphospecies 2, Penicillium, and Lasiodiplodia. T. asperellum was only found from all treated shallot with this fungus, whereas from untreated shallot, Trichoderma at low level was only detected in second treatment (Fig. 4). The total colonization of fungi in leaf tissues of untreated and treated shallot with mulch,

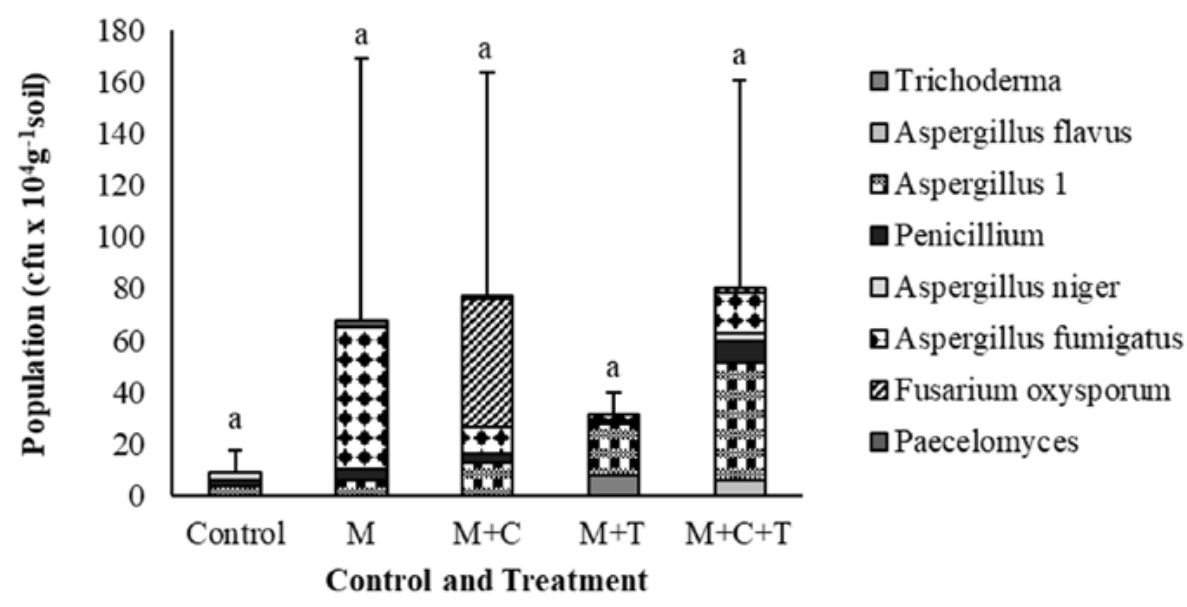

Fig. 3. Fungal population in soil assessed at harvesting time, 63 days after treatment by mulch, mulch plus compost, mulch plus Trichoderma asperellum, and mulch plus compost plus $T$. asperellum. $\mathrm{M}=$ mulch, $\mathrm{C}=\operatorname{compost}, \mathrm{T}=T$. asperellum. Means of population at the same time, followed by the same letter are not significantly different according to DMRT ( $p \leq 0.05$ ). Vertical bars show standard errors of means. 
mulch plus compost, mulch plus Trichoderma, and mulch plus compost plus Trichoderma were $60 \%, 25 \%, 60 \%, 105 \%$, and $100 \%$ and the fungal colonization in root tissues were $65 \%, 85 \%, 115 \%$, $115 \%$, and $113 \%$, respectively. F. oxyspoum as pathogen remained to persist in the root tissues. But it was removed from leaf tissues of shallot treated with T. asperellum (Fig. 4). Therefore, the number and colonization of fungal species were in general higher in treated than in untreated shallot. Statistical analysis indicated that between second, third, and fourth applications and control and between each this treatment in leaf tissues was not significantly different. While in root tissues, all treatments except for first treatment was significantly different $(P \leq 0.05)$ with control.

\section{DISCUSSION}

Soil-borne pathogens are conformed to grow, develop and survive in the soil and use the infection site to establish a plant-parasite relationship (Raaijmakers et al., 2009). As one of these pathogens, Fusarium oxysporum f.sp. cepae infects the roots or the basal plate of the bulbs causing basal bulb rot of shallot and can also affect bulb scales later in the season causing bulb damage in the storage (Entwistle, 1990). This incidence is likely related to the establishment of fungus in

$\mathbf{A}$

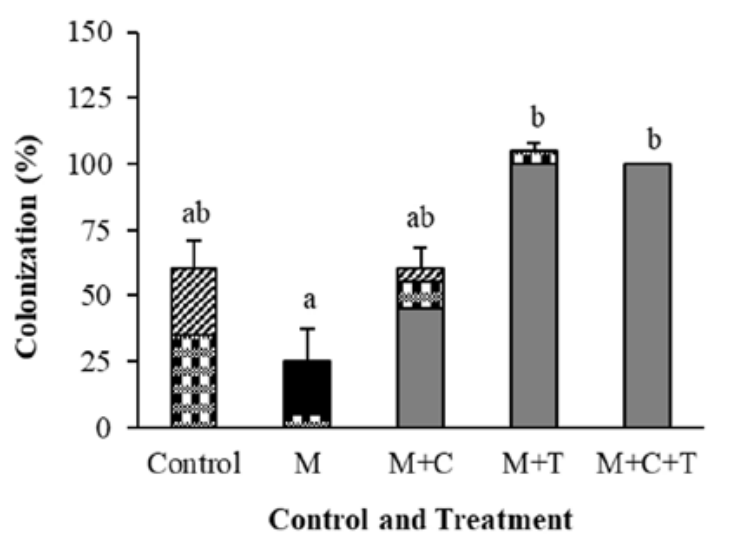

口Trichoderma

Aspergillus 1

שFusarium oxysporum

- Lasiodiplodia

B

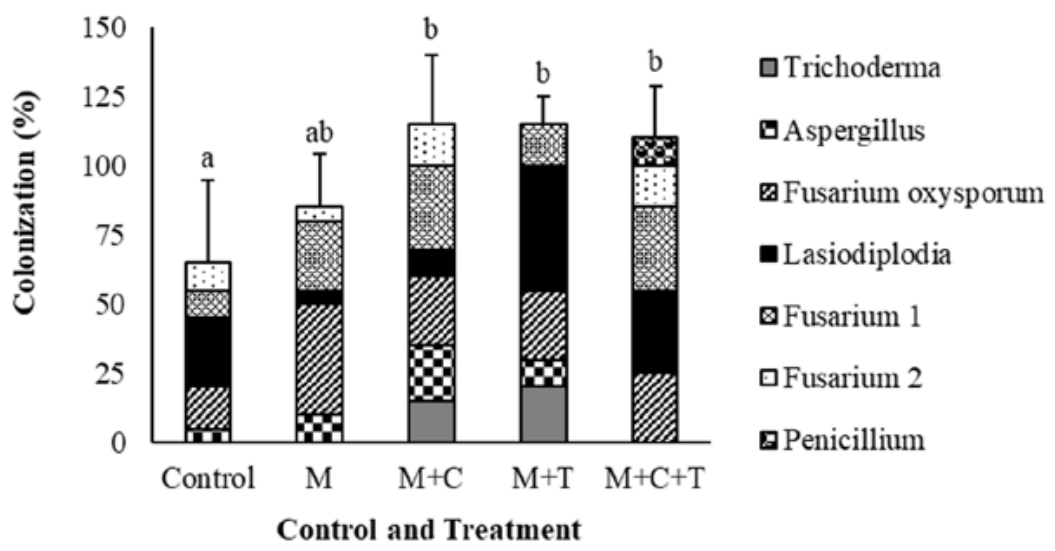

Fig. 4. Fungal colonization in leaf (A) and root (B) tissues observed at harvesting time, 63 days after treatment by mulch, mulch plus compost, mulch plus Trichoderma asperellum, and mulch plus compost plus T. asperellum. M $=$ mulch, $C=$ compost, $T=T$. asperellum. Means of colonization at the same time, followed by the same letter are not significantly different according to DMRT $(p \leq 0.05)$. Vertical bars show standard errors of means. 
root and leaf tissues, as shown in Fig. 3 and 4. The approach that can push beneficial microorganism activities in the rhizosphere is needed to limit the activities and the densities of pathogens to a harmless level (Janvier et al.,2007).

In this work, covering of soil surface with dry Imperata offered a negative impact on this disease. Many studies indicate that natural or plant residue mulches application may control weeds, conserve soil moisture and temperature, augment soil organic matter, and improve biological activity (Cook et al., 2006; Chalker-Scott, 2007). In the case of biological activity, the observation showed that the application of mulch tended to increase fungal population in soil and colonization in roots. Soil fungi included Aspergillus spp., Penicillium, and Paecillomyces, while endophytic root fungi consisted of Fusarium 1, Fusarium 2, Lasiodiplodia, and Aspergillus. This increase in the fungal community likely played an essential role in reducing BBR incidence. Microbial diversity, composition, and population density are one of the keys factors in the determination of pathogen control (Tuitert et al.,1998; Garbeva et al., 2006; Naseri and Mousavi, 2015).

Amendment of composted plant residues in combination with Imperata mulch tended to provide more inhibition of BBR than that treated with mulch alone. This treatment presented the highest colonization of fungi in roots, including Trichoderma. Suppression of plant disease by compost could be associated with enlarged beneficial microorganism activities that compete with pathogens for resources of substrate, the release of fungitoxic compounds during decomposition, and the systemic resistance induction in host plants called as systemic acquired resistance (SAR) (Bonanomi et al., 2010; Bonanomi et al., 2011; Kavroulakis et al., 2005). In compost, populations of Trichoderma often are abundant (Hoitink and Boehm, 1999). By regarding lower capacity in the colonization of shallot tissues and BBR suppression, Trichoderma species found in this mulch plus compost treatment was probably different from that introduced in the mulch plus Trichoderma and mulch plus compost plus Trichoderma treatments.

The suppression of BBR enhanced when into the soil, Trichoderma was drenched or amended. From this site, the fungus penetrated roots and reached the leaf (Fig. 4) permitting to offer inhibition to pathogen directly and indirectly. Direct inhibition is based on the ability of Trichoderma to parasitize and to produce antibiotics (Harman et al., 2008). Trichoderma also efficiently induce systemic resistance (ISR) as indirect inhibition against pathogens (Harman, 2011; Vitti et al., 2016). The removal of pathogen F. oxysporum, especially from leaf tissues may be attributed to the role of $T$. asperellum action supported by other beneficial fungi.

T. asperellum amended with compost and covering the soil surface with mulch offered the highest impact in disease suppression. There was likely a synergism action provided by this combination. The first synergism could probably be due to better growth of Trichoderma in the presence of compost and mulch. Compost served as a source of nutrition, while mulch acted as a conserver of compost and soil moisture. Trichoderma can grow and develop in composted plant residues (Hoitink et al., 2006; Rosmana et al., 2018a). Secondly, both Trichoderma and compost can induce plant resistance. Synergism could be, therefore, due to interaction between the two. Through compost, plants engage SAR to limit pathogen extension in systemic tissues by inducing necrosis at the local site upon primary infection (Durrant and Dong, 2004; Glazebrook, 2005). While through Trichoderma, ISR is not only induced by the interaction of the plant with Trichoderma, but is also initiated by pathogens (Djonovic et al., 2006). Thirdly, fungi stimulated their presence both by compost and mulch together with Trichoderma may offer the suppression on the disease (Ros et al., 2017). In the shallot treated with Trichoderma, the population in soil and colonization, especially in root tissues of fungi other than Trichoderma, tended to be higher than untreated shallot.

The increasing of shallot productivity may have been a consequence of treatment impact beside on BBR reduction, also on the plant growth promotion. Compost can support better grow of plant and increase their leaf content on potassium (Rosmana et al., 2019). Also, Trichoderma has the capability to improve plant growth, nutrient uptake, the efficiency of fertilizer use, and rate and percentage of seed germination (Shoresh et al., 2010). In other hands, Trichoderma is found useful as a compost activator by enhance the nutrient 
content of the compost, such as NPK (Lovez et al., 2015)

\section{CONCLUSION}

The work concludes that all treatments consisting of mulch, the combination of mulch and compost, the combination of mulch and $T$. asperellum, and integration of mulch, compost, and $T$. asperellum could control basal bulb rot in the field. However, the last treatment presented the most effective and Trichoderma had a role the most important in the suppression of pathogen. Shallot productivity with this treatment was $1316.9 \mathrm{~kg} \mathrm{ha}^{-1}$ or the increase by $125 \%$. Many farmers in the Palu valley where the trial occurred are aware that the use of synthetic pesticides in high frequency could be hazardous for their health and environment. Therefore, these results can be beneficial for them, and they may choose the above treatment according to their abilities. Furthermore, the present findings improved the current knowledge on the sustainable management of shallot basal bulb rot that need further research to be confirmed for different areas.

\section{ACKNOWLEDGMENTS}

The authors are grateful to the Indonesian Agency for Agricultural Research and Development, Ministry of Agriculture who have supported this research.

\section{CONFLICT OF INTEREST}

The authors declare that there is no conflict of interest.

\section{AUTHORS' CONTRIBUTION}

Conceptualization, $\mathrm{NI}$ and $\mathrm{AR}$; methodology, $\mathrm{NI}$ and SS; formal analysis, $\mathrm{NI}$ and AR; investigation, $\mathrm{NI}$ and RR; resources, AR and SS; data curation, $\mathrm{NI}$; writing - original draft preparation, $\mathrm{NI}$ and AR; writing - review and editing, AR and SS; work administration, RR; funding acquisition, NI.

\section{FUNDING}

This study was scholarship grant offered by Indonesian Ministry of Agriculture with a decree No. 51/Kpts/KP320/A/01/2019.

\section{ETHICS STATEMENT}

This article does not contain any studies with human participants or animals performed by any of the authors.

\section{DATA AVAILABILITY}

All datasets generated or analyzed during this study are included in the manuscript

\section{REFERENCES}

1. Adiyoga W, de Putter H. Pesticide use in shallot-hot pepper intercropping cultivation system in Brebes, Central Java. ISHS Acta Hortic. 2015;1105. https://doi. org/10.17660/ActaHortic.2015.1105.32

2. Anshary AA, Basri Z, Toana H. Effect of chemical insecticides on the arthropod diversity in the agro- ecosystem of red onion crops. Asian J Crop Sci. 2018;10:107-114. https://doi.org/10.3923/ ajcs.2018.107.114

3. Arnold AE, Mejia LC, Kyllo D, Rojas EI, Maynard Z, Robbins N, Herre EA. Fungal endophytes limit pathogen damage in a tropical tree. Proc Nat Acad Sci USA. 2003;100:15649-15654. https://doi. org/10.1073/pnas.2533483100

4. Bailey BA, Strem MD, Wood D. Trichoderma species form endophytic associations within Theobroma cacao trichomes. Mycol Res. 2009;113:1365-1376. https:// doi.org/10.1016/j.mycres.2009.09.004

5. Bajwa WI, Kogan M. Cultural practices: springboard to IPM. In: Koul O, Dhaliwal GS, Cuperus GW (Eds.). Integrated Pest Management: Potential, Constraints and Challenges. CABI Publishing, Wallingford, UK, 2004; 21-38. https://doi.org/10.1079/9780851996868.0021

6. Barnett HL, Hunter BB. Illustrated genera of imperfect fungi. APS Press, St. Paul, USA, 1998:218.

7. Singh $B$, Rengel $Z$. The role of crop residues in improving soil fertility. In Marschner P and Rengel Z (Eds.). Nutrient Cycling in Terrestrial Ecosystems, Soil Biology. Springer-Verlag Berlin Heidelberg. 2007;10:183-214.

8. Bonanomi G, Antignani V, Capodilupo M, Scala F. Identifying the characteristics of organic soil amendments that suppress soilborne plant diseases. Soil Biol. Biochem. 2010;42:136-144. https://doi. org/10.1016/j.soilbio.2009.10.012

9. Bonanomi G, Antignani V, Barile E, Lanzotti V, Scala F. Decomposition of Medicago sativo residues affects phytotoxicity, fungal growth and soil-borne pathogen diseases. J Plant Pathol. 2011;93:57-69.

10. Chalker-Scott L. Impact of mulches on landscape plants and the environment - a review. J Environ Horticul. 2007;25:239-249.

11. Cook HF, Valdes GSB, Lee HC. Mulch effects on rainfall interception, soil physical characteristics and temperature under Zea mays L. Soil Tillage Res. 2006;91:227-235. https://doi.org/10.1016/j. still.2005.12.007

12. Djonovic S, Pozo MJ, Dangott LJ, Howell CR, Kenerley CM. Sm1, a proteinaceous elicitor secreted by the biocontrol fungus Trichoderma virens induces plant 
defense responses and systemic resistance. $\mathrm{Mol}$ Plant Microbe Interact. 2006;19:838-853. https://doi. org/10.1094/MPMI-19-0838

13. Durrant WE, Dong X. Systemic acquired resistance. Annu Rev Phytopathol. 2004;42:185-209. https://doi. org/10.1146/annurev.phyto.42.040803.140421

14. Entwistle AR. Root diseases. In: Brewster $\mathrm{JL}$ (Ed.). Onions and Allied Crops. Boca Raton, FL, USA: CRC Press, 1990:103-154. https://doi. org/10.1201/9781351075152-6

15. Fadhilah S, Wiyono S, Surahman M. Development of detection technique for Fusarium pathogen on seedling shallot (Allium ascalonicum) bulb at Laboratory. J Hort. 2014;24:171-178. https://doi. org/10.21082/jhort.v24n2.2014.p171-178

16. Garbeva P, Postma J, van Veen JA, van Elsas JD. Effect of above-ground plant species on soil microbial community structure and its impact on suppression of Rhizoctonia solani AG3. Environ Microbiol. 2006;8:233-246. https://doi.org/10.1111/j.14622920.2005.00888.x

17. Glazebrook J. Contrasting mechanisms of defense against biotrophic and necrotrophic pathogens. Annu Rev Phytopathol. 2005;43:205-227. https://doi. org/10.1146/annurev. phyto.43.040204.135923

18. Harman GE, Bjorkman T, Ondik K, Shoresh M. Changing paradigms on the mode action and uses of Trichoderma spp. for biocontrol. Out looks on Pest Management. 2008. https://doi.org/10.1564/19feb08

19. Harman GE, Howell CR, Viterbo A, Chet I, Lorito M. Trichoderma species: opportunistic avirulent plant symbionts. Nat Rev Microbiol. 2004;22:43-56. https:// doi.org/10.1038/nrmicro797

20. Harman GE. Trichoderma-not just for biocontrol anymore. Phytoparasitica. 2011;39:103-108. https:// doi.org/10.1007/s12600-011-0151-y

21. Hoitink HAJ, Boehm MJ. Biocontrol within the context of soil microbial communities: A substrate-dependent phenomenon. Annu Rev Phytopathol. 1999;37:427446. https://doi.org/10.1146/annurev.phyto.37.1.427

22. Hoitink HAJ, Madden LV, Dorrance AE. Systemic resistance induced by Trichoderma spp.: Interactions between the host, the pathogen, the biocontrol agent, and soil organic matter quality. Phytopathology. 2006;96:186-189. https://doi.org/10.1094/ PHYTO-96-0186

23. Janvier $\mathrm{C}$, Villeneuve $\mathrm{F}$, Alabouvette $\mathrm{C}$, Edel-Hermann V, Mateille T, Steinberg C. Soil health through soil disease suppression: which strategy from descriptors to indicators? Soil Biol Biochem. 2007;39:1-23. https:// doi.org/10.1016/j.soilbio.2006.07.001

24. Kareem KT, Alamu OO, Ggberongbe RKE, Arogundade $O$. Effect of different mulch materials on the incidence and severity of okra mosaic virus (OMV) in okra plants. J Appl Horticul. 2012;14. https://doi.org/10.37855/ jah.2012.v14i01.09

25. Kavroulakis N, Ehaliotis C, Ntougias S, Zervakis GI, Kalliope K, Papadopoulou KK. Local and systemic resistance against fungal pathogens of tomato plants elicited by a compost derived from agricultural residues. Physiol Mol Plant Pathol. 2005;66:163-174. https://doi.org/10.1016/j.pmpp.2005.06.003
26. Kiffer E, Morelet M. The Deuteromycetes. Mitosporic fungi: classification and generic keys. Science Publishers Inc, Enfield, USA. 1997.

27. Lopez LLMA, Reyes RG, Alvindia DG. Evaluation of two species of Trichoderma as compost activator and biocontrol agents. J Agric Tech. 2015;11:525.

28. Naseri B. Epidemics of Rhizoctonia root rot in association with biological and physicochemical properties of field soil in bean crops. J Phytopathol. 2013;161:397-404. https://doi.org/10.1111/jph.12077

29. Naseri B, Mousavi SS. Root rot pathogens in field soil, root and seed in relation to common bean (Phaseolus vulgaris) disease and seed production. Intl J Pest Manag. 2015;61:60-67. https://doi.org/10.1080/096 70874.2014.993001

30. Ozer N, Koycu ND, Chilosi G, Pizzuolu PH, Coskuntuna A, Magro P. Pectolytic isoenzymes by Fusarium oxysporum f. sp. cepae and antifungal compounds in onion cultivars as a response to pathogen infection. Can. J Plant Pathol. 2003;25:249-257. https://doi. org/10.1080/07060660309507077

31. Pane C, Spaccini R, Piccolo A, Scala F, Bonanomi G. Compost amendments enhance peat suppressiveness to Pythium ultimum, Rhizoctonia solani and Sclerotinia minor. Biol Control. 2011;56:115-124. https://doi. org/10.1016/j.biocontrol.2010.10.002

32. Pane C, Piccolo A, Spaccini R, Celano G, Villecco D, Zaccardelli M. Agricultural waste-based composts exhibiting suppressivity to diseases caused by the phytopathogenic soil-borne fungi Rhizoctonia solani and Sclerotinia minor. Appl Soil Ecol. 2013;65:43-51. https://doi.org/10.1016/j.apsoil.2013.01.002

33. Raaijmakers JM, Paulitz TC, Steinberg C, Alabouvette $C$, Moenne-Loccoz Y. The rhizosphere: a playground and battlefield for soil-borne pathogens and beneficial microorganisms. Plant Soil. 2009;321:341-361. https:// doi.org/10.1007/s11104-008-9568-6

34. Ratnawati R, Sjam S, Rosmana A, Tresnapura US. Endophytic Trichoderma species of Palu valley shallot origin with potential for controlling purple blotch pathogen Alternariaporri. Intl J Agric Biol. 2020;22:977-982.

35. Ros M, Raut I, Santisima-Trinidad AB, Pascual JA. Relationship of microbial communities and suppressiveness of Trichoderma fortified composts for pepper seedlings infected by Phytophthora nicotianae. PLOS ONE. 2017;12:e0174069. https://doi. org/10.1371/journal.pone.0174069

36. Rosmana A, Nasaruddin N, Hendarto H, Hakkar AK, Agriansyah A. Endophytic association of Trichoderma asperellum within Theobroma cacao suppresses vascular streak dieback incidence and promotes side graft growth. Mycobiology. 2016;44:180-186. https:// doi.org/10.5941/MYCO.2016.44.3.180

37. Rosmana A, Kuswinanti T, Asman A, Mandy YI, Muhayang MT, AM Kesia AM. Composted plant residues improve control capability of Trichoderma asperellum against vascular streak disease on cacao. Intl J Agric Biol. 2018a;20:1795-1800.

38. Rosmana A, Sjam S, Asman A, Jayanti NJ, Satriana S, Padang, AT, Hakkar AA. Systemic deployment of Trichoderma asperellum in Theobroma cacao 
regulates co-occurring dominant fungal endophytes colonization. J Pure Appl Microbiol. 2018b;12:10711084. https://doi.org/10.22207/JPAM.12.3.05

39. Rosmana A, Sakrabani R, Sjam S, Nasaruddin N, Asman A, Pandin BYS. Plant residue based-composts applied in combination with Trichoderma asperellum improve cacao seedling growth in soil derived from nickel mine area. J Animal Plant Sci. 2019;29:291-298.

40. Segarra G, Santpere G, Georgina Elena G, Trillas I. Enhanced Botrytis cinereal resistance of Arabidopsis plants grown in compost may be explained by increased expression of defense-related genes, as revealed by microarray analysis. PLOS ONE. 2013;8:e56075. https://doi.org/10.1371/journal. pone. 0056075

41. Shoresh M, Harman GE, Mastouri F. Induced systemic resistance and plant responses to fungal biocontrol agents. Annu Rev Phytopathol. 2010;48:21-43. https:// doi.org/10.1146/annurev-phyto-073009-114450

42. Stirling GR, Eden LM. The impact of organic amendments, mulching and tillage on plant nutrition, Pythium root rot, root-knot nematode and other pests and diseases of capsicum in a subtropical environment, and implications for the development of more sustainable vegetable farming systems. Australian Plant Pathol. 2008;37:123-131. https://doi. org/10.1071/AP07090

43. Tuitert G, Szczech M, Bollen GJ. Suppression of Rhizoctonia solani in potting mixtures amended with compost made from organic house hold waste. Phytopathology. 1998;88:764-773. https://doi. org/10.1094/PHYTO.1998.88.8.764

44. Vitti A, Pellegrini E, Nali C, et al. Trichoderma harzianum $\mathrm{T}-22$ induces systemic resistance in tomato infected by cucumber mosaic virus. Frontiers in Plant. Science, 2016;7:Article1520. https://doi.org/10.3389/ fpls.2016.01520

45. Wandschneider T, Andri KB, Ly K, et al. Shallot value chain study. Eastern Indonesia-Agribusiness Development Opportunities (EI-ADO), ACIAR, Australia. 2013;9. 